University of Nebraska - Lincoln

DigitalCommons@University of Nebraska - Lincoln

$5-1-2003$

\title{
The Instructional Use and Teaching Preparation of Graduate Students in U.S. Ph.D.-Granting Economics Departments
}

\author{
WILLIAM WALSTAD \\ University of Nebraska-Lincoln, wwalstad1@unl.edu \\ William E. Becker \\ Indiana University - Bloomington, beckerw@iu.edu
}

Follow this and additional works at: https://digitalcommons.unl.edu/cbafacpub

Part of the Business Commons

WALSTAD, WILLIAM and Becker, William E., "The Instructional Use and Teaching Preparation of Graduate Students in U.S. Ph.D.-Granting Economics Departments" (2003). College of Business Faculty Publications. 40.

https://digitalcommons.unl.edu/cbafacpub/40

This Article is brought to you for free and open access by the Business, College of at DigitalCommons@University of Nebraska - Lincoln. It has been accepted for inclusion in College of Business Faculty Publications by an authorized administrator of DigitalCommons@University of Nebraska - Lincoln. 


\title{
PREPARING AND IMPROVING THE ECONOMICS TEACHER ${ }^{\dagger}$
}

\section{The Instructional Use and Teaching Preparation of Graduate Students in U.S. Ph.D.-Granting Economics Departments}

\author{
By William B. Walstad and William E. BeckeR*
}

Graduate students are employed extensively in the teaching of economics at the undergraduate level, but little is known about how they are used for instruction and how they are prepared for their teaching duties. To investigate this topic, we prepared a survey and sent it to the chairs of all $100 \mathrm{Ph} . \mathrm{D}$.-granting economics departments. ${ }^{1}$

The survey was designed to elicit information on (i) the size of Ph.D. economics programs and the uses of graduate students for undergraduate instruction, (ii) the provision of credit and noncredit courses in teaching for economics graduate student instructors, (iii) teaching programs for international graduate students serving as economics instructors, and (iv) the uses of teaching evaluation for graduate-student instructors in economics. Two members of the AEA Committee on Economic Education reviewed initial drafts of the survey. Several economists with extensive experience in survey work and the teaching preparation of economics graduate students also provided constructive

\footnotetext{
${ }^{\dagger}$ Discussants: KimMarie McGoldrick, University of Richmond; Stephen Buckles, Vanderbilt University; Thomas Husted, American University.

* Walstad: Department of Economics, University of Nebraska, Lincoln, NE 68588-0402 (e-mail: wwalstad1@ unl.edu); Becker: Department of Economics, Indiana University, Bloomington, IN 47405, and School of International Business, University of South Australia (e-mail: beckerw@indiana.edu). We thank Sharon Nemeth and Hallie Klein with help in mailing and data entry. Dan Hamermesh, John Siegfried, Michael Watts, and Michael Salemi provided helpful comments in preparing the survey.

${ }^{1}$ The department list was based on a research ranking study (Jerry G. Thursby, 2000). Although it listed 104 departments, only 100 were used for this study. Four departments in the lower third of departments were omitted because one program ended in 1999, another had not admitted students since 1997, and two others offered a specialized degree.
}

criticism. It underwent five revisions before it was sent to department chairs via regular mail in mid-August 2002.

We received 85 of 100 surveys mailed. This high response rate was achieved through two follow-up mailings to nonresponding chairs, and by assuring all respondents that only the aggregate findings would be reported. The response rate was also high across departments, regardless of research ranking (see Thursby, 2000). It was 88 percent for the top third of departments, 97 percent for the middle third, and 71 percent for the lowest third. The higher response rate for the middle third is probably because more graduate students teach at these mostly large, public universities. The lower response rate for the bottom-third departments reflects some difficulty in contacting their chairs; but it might also indicate less activity to report.

\section{Department Characteristics and Teaching Duties}

The mean size of Ph.D. departments of economics was 65 students. Thursby's highest ranked departments (1-33) reported an average of $102 \mathrm{Ph} . \mathrm{D}$. economics students typically enrolled each year. Only $51 \mathrm{Ph} . \mathrm{D}$. economics students, on average, were enrolled in the middle third of ranked departments. For economics departments ranked in the lowest third, the yearly mean enrollment dropped to $41 \mathrm{Ph} . \mathrm{D}$. students.

As might be expected, the entry and exit of graduate students varied substantially across these economics departments. The number of new graduate students admitted to $\mathrm{Ph} . \mathrm{D}$. economics departments ranged from 3 to 35 $($ mean $=15.7, \mathrm{SD}=7.9)$. For the upper third of departments the mean was 23 ; for the middle third it was 14; and for the lowest third it was 9 . 
As for an exit measure, the number of Ph.D. degrees in economics awarded each year by a department ranged from 2 to 30 (mean $=8.2$, $\mathrm{SD}=6.0$ ). The top third of departments, however, awarded more than double the number of $\mathrm{Ph} . \mathrm{D}$. degrees in economics (13.3 degrees) compared with the middle third (6.4) or the bottom third (4.3).

Graduate students in economics are assigned to undergraduate education duties based on experience. In the first or second year of their Ph.D. program (1.4 years on average), graduate students typically develop their teaching skills through assisting professors with grading exams and by serving as tutors for courses. They do not teach at this point of the program, presumably because they have not taken enough economics courses to ensure that they have sufficient content knowledge, or because more experienced graduate students have filled all the teaching slots. The assistant work requires about 15-16 hours of their time per week. There is little variation in these characteristics across rankings of $\mathrm{Ph} . \mathrm{D}$. economics departments.

Using graduate students to lead recitation sections is a second popular form of employment. In this role, graduate students do not teach their own courses, but lead discussions and other small classroom activities that are to complement large classroom lectures taught by faculty members two or three times per week. A recitation section usually meets only once per week compared with two or three class meetings that would be required for graduate students teaching their own courses. Graduate students generally begin this instruction during the first two years of their Ph.D. program (1.6 years on average). They lead an average of about seven (7.3) term-long recitation sections per academic year, and this number varies little across differently ranked departments. The recitation sections typically enroll about 231 students in total during the academic year (or 32 students per section).

Graduate students do not tend to get their own courses until the third year of their graduate program. The mean teaching load is then about three courses (2.6), with 120 students per academic year (about 46 students per course). It is somewhat lighter than average in the top third (1.9 courses) and bottom third (1.9 courses) of ranked departments. The heaviest teaching load
(3.6 courses) is for those students in the middle third of ranked departments, who teach almost double the number of courses (1.7 more) than their counterparts in the top or bottom thirds of departments. The likely explanation, as already stated, is that the middle-ranked departments are often located in large state universities that have a high demand for teaching services, and these departments respond by having graduate students teach more courses.

It is also possible to describe the distribution of graduate students across teaching and research duties based on the sample averages from the survey. Consider a department with an average size of 65 students in the $\mathrm{Ph} . \mathrm{D}$. program that reports using graduate students for the three types of instruction. About 20 percent (13 students) would assist professors with their courses; about 28 percent (18 students) would lead recitation sections; and about 12 percent ( 8 students) would be assigned to teach their own courses. The remaining 40 percent (26 students) would do something else, such as serve as research assistants or not have any assistantship.

The above distribution will obviously differ by department and across department types. For example, although there is no basic difference in the average number of economics graduate students teaching their own courses or assisting professors across each ranking third, there is an important difference in the use of graduate students for recitation sections. Economics departments in the top third use an average of 32 graduate students to lead recitations, more than double the 13 students used by the middle third, and more than triple the nine students used in the bottom third. In addition, some differences arise because some Ph.D. programs do not use graduate students for teaching, perhaps because they use them only as research assistants. Eight departments do not use any graduate students to assist professors with their teaching. Fifteen departments do not have graduate students lead recitation sections. Twelve departments do not have graduate students teach their own courses.

\section{Teaching Requirements, Courses, and Programs}

Teaching a course or leading a recitation section is an important instructional duty that, if 
not handled well, can hurt a department by increasing student complaints, decreasing majors, and negatively affecting the employment potential of graduate students. To avoid these outcomes, departments have established requirements for graduate-student instructors. Among the departments that employ graduate student instructors $(n=72)$, only about a quarter $(n=$ 16) require them to attend a graduate-credit course in undergraduate teaching. A common requirement for about half of these departments $(n=33)$ was to have them attend a noncredit program on undergraduate teaching. ${ }^{2}$ Also popular for about half of these departments $(n=35)$ was having graduate students assist a faculty member before teaching their own courses. About a quarter $(n=18)$ of the departments listed other actions such as having students pass comprehensive exams. A requirement covering about four-fifths ( $n=58)$ of these departments was to have international students pass an English-language test before they were allowed to teach their own courses.

The requirements for leading recitation sections were similar to those for teaching a course among the departments using recitation leaders $(n=64)$. Less than a fifth $(n=10)$ of these departments selected the most demanding option, a graduate-credit course in undergraduate teaching. By contrast, about half $(n=34)$ required the less-demanding option of attendance at a noncredit program on teaching. About a third of these departments $(n=22)$ wanted graduate students to assist a faculty member before leading a recitation section. As was the case with teaching a course, about fourfifths of these departments $(n=53)$ required international graduate students to pass an Englishlanguage test before leading a recitation section.

The credit courses designed to prepare an economics graduate student for teaching an undergraduate course or leading a recitation section are of two types at the universities that offer them $(n=29)$. In about two-thirds of the cases

\footnotetext{
${ }^{2}$ John J. Siegfried and Rendigs Fels (1979) concluded from a review of several 1970's research studies that graduate students who have had teacher training are better instructors than those who have not. Although this past research lacks the statistical rigor expected of empirical work today, no credible study to date has overturned this conclusion.
}

$(n=19)$, the economics department sponsors the course, and its students are the primary enrollees. In the remaining one-third of the cases $(n=10)$, economics graduate students take a course sponsored by an education department or a campus teaching and learning center. If economics departments offer these courses, then 93 percent of economics graduate students take them compared with only 20 percent of the students who take them when the courses are offered by another unit at a university.

The interest in these teaching courses sponsored by economics departments $(n=19)$ differs across differently ranked departments. Over half $(n=10)$ of these teaching courses are found at the middle third of ranked departments. The rest are offered at universities with economics departments either in the upper third $(n=6)$ or the lower third $(n=3)$ of department rankings. Again, the likely reason why middle-ranked departments offer this teaching resource more often is that they require more course teaching of their graduate students, and these instructors handle heavier teaching loads. There may be pressure on these departments, often located at large state universities, to demonstrate that they do a good job of preparing graduate-student instructors and to reduce student complaints. Given these circumstances, it should not be surprising that 80 percent of graduate students who take courses sponsored by the middle third of economics departments do so before they teach their own courses. At the top third of economics departments, the departmentsponsored courses are more likely to be taken either while teaching a course (33 percent) or at any time during a $\mathrm{Ph} . \mathrm{D}$. program (33 percent).

The amount of credit awarded for the economics department courses $(n=19)$ is about three credit hours (2.8) when they are offered on a semester basis, or four credit hours when they are done on a quarter basis. As for grading, about four-fifths ( $n=15$ ) of the courses use pass or fail, and about one-fifth $(n=4)$ use letter grades. The primary instructors in about four-fifths of the cases $(n=15)$ are economics faculty members. This instruction from the economics faculty member is supplemented with presentations from two or three other members of the economics faculty in about half of these courses $(n=10)$. A few of these courses $(n=3)$ include presentations from about two 
non-economics faculty members who are teaching specialists.

Another approach to teacher preparation is through noncredit programs that are available to economics graduate students at about half of the universities $(n=55)$. These programs are either offered by economics departments $(n=$ 18 ) or by another unit at the university $(n=37)$. About half of the economics graduate students who take these noncredit programs on teaching offered either by the economics department or another unit do so before they teach their own courses or lead recitation sections.

As was the case with credit courses, economics graduate students are more likely to attend these noncredit programs when offered by an economics department (90 percent attend) rather than another university unit on campus (only about 62 percent attend). One of the reasons for the attendance difference may be associated with instructors. When economics departments offer noncredit programs in teaching, an economics faculty member is primarily responsible for instruction in about two-thirds $(n=12)$ of the programs. In addition, in over half the programs $(n=10)$, several economics faculty members make presentations. By contrast, economics faculty are not involved in university-sponsored programs except for an occasional presentation. ${ }^{3}$

The increase in the number of economics graduate students coming from other nations has raised questions about their preparation for teaching. As already noted, most economics departments require that international graduate students pass an English-language test before they teach a course or lead a recitation section. There are other resources to assist international

\footnotetext{
${ }^{3}$ Academic economists often state that their aim is to get students to think like economists because they think there is something special about critical thinking in economics versus other disciplines. Similarly, chemists John Garratt et al. (2000) proclaim that their job is to get students to think like chemists, and they go on to show how this unique aptitude is advanced through alternative teaching methods and student activities. Unlike these chemists, however, economists who are willing to leave the teacher training of their students to non-economists are not practicing what they preach. Contrary to the fundamental assumption behind general books on instructional methods, teaching any discipline within higher education consists of a blend of generic teaching skills combined and weighted heavily with the ethos of the discipline, which general education specialists cannot provide.
}

students with their teaching. Over four in ten $(n=35)$ of the economics departments reported that a unit at their university offers a credit or noncredit program on undergraduate teaching that is taken only by international graduate students. About a fourth $(n=8)$ of the universities offer international graduate students a credit course in teaching that allows them to earn about 2-3 credit hours. The other three-fourths ( $n=27)$ of universities provide a noncredit course that lasts about 14 hours, on average. Economics departments at these universities estimate that about 66 percent of the international graduate students in economics take the credit course or attend the noncredit program. As might be expected, the great majority of these international graduate students attend this program either before leading a recitation section ( 74 percent) or before teaching their own course (62 percent). ${ }^{4}$

\section{Evaluation of Graduate Student Teaching}

The evaluation of graduate-student instruction is taken seriously by most economics departments. In fact, 93 percent of the departments conduct formal annual evaluations of the teaching of graduate students who teach their own courses ( $n=67$ of 72). Among the departments that evaluate $(n=67)$, the multiple responses for this question showed that the evaluation is overseen by the department chair in over half the cases $(n=38)$ and by the director of graduate studies in less than half of the cases $(n=28)$. For less than a quarter of the cases it is overseen by the director of undergraduate studies $(n=16)$, an economics faculty member $(n=13)$, or by someone else $(n=12)$ such as from a teaching and learning center. Rarely does a senior graduate assistant handle the evaluation $(n=3)$.

Economics departments used different methods to evaluate the teaching of graduate students

\footnotetext{
${ }^{4}$ Belton Fleisher et al. (2002) assessed the effect of foreign graduate students and native English speakers teaching undergraduates when the undergraduate economics instruction is in English. They found no difference in the grading of students and persistence of the students in the study of economics, provided the graduate students are properly selected and trained in both spoken English and in teaching methods.
} 
who teach their own courses. The most common method, used in all cases $(n=67)$, was data from the end-of-term student evaluations of teaching. ${ }^{5}$ In almost half of the cases, departments used faculty visits to courses $(n=31)$ or reviewed course materials $(n=32)$. The methods less often used were a meeting between the graduate-student instructor and department chair or faculty member ( $n=17)$, videotaping of graduate-student instructors $(n=9)$, chair visitations to courses taught $(n=7)$, or some other method $(n=5)$.

The annual evaluations of graduate-student instructors affect work assignments rather than pay. Almost 90 percent of the departments ( $n=$ 59) use the evaluations to make teaching appointments in the subsequent year, but it is likely to affect workloads in a subsequent year in just over a quarter $(n=19)$ of departments. Few departments use the evaluation to change the rate of compensation $(n=5)$, but some departments $(n=12)$ say it can affect the graduate-student instructor in other ways, such as for recommendations for teaching awards or reference letters.

Economics departments that evaluate students $(n=67)$ provide other opportunities for those students to improve their instruction. Over half of the departments $(n=37)$ reported that faculty members mentor graduate students interested in teaching, and about a third $(n=22)$ reported that there is mentoring by senior or experienced graduate-student instructors. Students are often encouraged by about two-fifths of departments $(n=27)$ to attend teaching sessions offered by another campus unit, but the department activity in this area is limited because only about a quarter of these economics departments ( $n=15$ ) report that they offer such teaching sessions.

\section{Conclusions}

The final question asked chairs to rate the preparation for teaching of their graduate students on a five-point scale (very good to very

\footnotetext{
${ }^{5}$ Becker (2000 pp. 113-16) provides six reasons why end-of-term student evaluations of instruction and instructors should not be the sole measure of teaching. Ideally feedback should be gathered by a variety of methods throughout the term.
}

poor). This question was answered by 84 of the 85 departments returning surveys. Most of the respondents gave a positive rating: 23 percent, very good; and 38 percent, good. About a third (35 percent) checked "adequate" and 5 percent admitted to doing a poor job. There was minimal difference across departments by rankings. These ratings appear to be inconsistent with what the chairs had reported was being done to prepare graduate students for teaching: few economics departments either offer or require graduate students to take a graduate-credit course on teaching economics ( $n=17-19)$.

Although more economics departments require graduate students to complete some type of noncredit program on undergraduate teaching $(n=35)$, the value of this approach often depends on the length of the program and the quality of the noncredit instruction. The number of hours for such noncredit programs varies from about 3 to 40 hours, with a mean of 13 hours for programs sponsored by the economics department and 11 hours for university-sponsored programs. This amount of time is between onethird to two-thirds less than the instructional time in a credit course on teaching. Such noncredit programs, especially the shorter ones, will only offer the graduate students an introduction to teaching. There will hardly be the time to develop a wide range of teaching skills or time to learn about newer teaching innovations in economics that take students beyond "chalk and talk" (Becker and Michael Watts, 2001). ${ }^{6}$ In addition, the noncredit programs that are offered by another university unit are not likely to meet the instructional and content needs of economics graduate students, and economics students are less likely to attend them.

Perhaps most telling is the gap between teaching demands on graduate students and their teaching preparation at many schools. About 40 percent of economics departments that permit students to teach their own courses do not require either a graduate-credit course in teaching or a noncredit program as preparation

\footnotetext{
${ }^{6}$ Another option would be for economics faculty members to attend workshops on teaching economics after they receive their $\mathrm{Ph} . \mathrm{D}$.'s and take a teaching job. While such programs are beneficial, they are not widely available, and the faculty members who need teaching help may decide not to attend (Michael K. Salemi et al., 1996).
} 
or support for the teaching experience. Of course, an argument could be made that assisting an older, established faculty member in grading or tutoring should also count as adequate preparation, or that student teaching is easily monitored by course evaluations, but these practices are hardly sufficient help for teaching courses. Even economics departments that do not use graduate students for instruction still have a responsibility to provide them with a solid preparation in teaching, because these future Ph.D. economists are likely to be teaching during their careers.

\section{REFERENCES}

Becker, William E. "Teaching Economics in the 21st Century." Journal of Economic Perspectives, Winter 2000, 14(1), pp. 109-19.

Becker, William E. and Watts, Michael. "Teaching Economics at the Start of the 21st Century: Still Chalk-and-Talk." American Economic Review, May 2001 (Papers and Proceedings), 91(2), pp. 446-51.
Fleisher, Belton; Hashimoto, Masanori and Weinberg, Bruce A. "Foreign GTAs Can be Effective Teachers of Economics." Journal of Economic Education, Fall 2002, 33(4), pp. 299-326.

Garratt, John; Overton, Tina; Tomlinson, Jane and Clow, Doug. "Critical Thinking Exercises for Chemists: Are They Subject Specific?" Active Learning in Higher Education, 2000, I(2), pp. 152-67.

Salemi, Michael K.; Saunders, Phillip and Walstad, William B. "Teacher Training programs in Economics: Past, Present, and Future." American Economic Review, May 1996 ( $P a-$ pers and Proceedings), 86(2), pp. 460-64.

Siegfried, John J. and Fels, Rendigs. "Teaching College Economics: A Survey." Journal of Economic Literature, September 1979, 17(3), pp. 923-69.

Thursby, Jerry G. "What Do We Say about Ourselves and What Does It Mean? Another Look at Economics Department Research." Journal of Economic Literature, June 2000, 38(2), pp. 383-404. 